\title{
Development of a bead-based Luminex assay using lipopolysaccharide specific monoclonal antibodies to detect biological threats from Brucella species
}

\author{
Angelika Silbereisen ${ }^{1,2}$, Marco Tamborrini ${ }^{1,2}$, Matthias Wittwer ${ }^{3}$, Nadia Schürch $^{3}$ and Gerd Pluschke , $^{1,2^{*}}$
}

\begin{abstract}
Background: Brucella, a Gram-negative bacterium, is classified as a potential bioterrorism agent mainly due to the low dose needed to cause infection and the ability to transmit the bacteria via aerosols. Goats/sheep, cattle, pigs, dogs, sheep and rodents are infected by B. melitensis, B. abortus, B. suis, B. canis, B. ovis and B. neotomae, respectively, the six classical Brucella species. Most human cases are caused by B. melitensis and B. abortus. Our aim was to specifically detect Brucellae with 'smooth' lipopolysaccharide (LPS) using a highly sensitive monoclonal antibody (mAb) based immunological assay.

Methods: To complement molecular detection systems for potential bioterror agents, as required by international biodefense regulations, sets of mAbs were generated by B cell hybridoma technology and used to develop immunological assays. The combination of mAbs most suitable for an antigen capture assay format was identified and an immunoassay using the Luminex XMAP technology was developed.

Results: MAbs specific for the LPS O-antigen of Brucella spp. were generated by immunising mice with inactivated B. melitensis or B. abortus cells. Most mAbs recognised both B. melitensis and B. abortus and antigen binding was not impeded by inactivation of the bacterial cells by $\gamma$ irradiation, formalin or heat treatment, a step required to analyse the samples immunologically under biosafety level two conditions. The Luminex assay recognised all tested Brucella species with 'smooth' LPS with detection limits of $2 \times 10^{2}$ to $8 \times 10^{4}$ cells per $\mathrm{mL}$, depending on the species tested. Milk samples spiked with Brucella spp. cells were identified successfully using the Luminex assay. In addition, the bead-based immunoassay was integrated into a multiplex format, allowing for simultaneous, rapid and specific detection of Brucella spp., Bacillus anthracis, Francisella tularensis and Yersinia pestis within a single sample.
\end{abstract}

Conclusion: Overall, the robust Luminex assay should allow detection of Brucella spp. in both natural outbreak and bio-threat situations.

Keywords: Brucellosis, Luminex, Antigen capture assay, Monoclonal antibodies, Multiplex

\section{Background}

Brucellosis, a zoonotic bacterial disease caused by Gram-negative Brucellae and classified as a potential bioterrorism disease [1], leads to abortions in animals and flu-like symptoms with periodic bouts of fever in humans. B. melitensis, B. abortus, B. suis, B. canis, B.

\footnotetext{
* Correspondence: gerd.pluschke@unibas.ch

'Department of Medical Parasitology and Infection Biology, Swiss Tropical and Public Health Institute, Basel, Switzerland

2University of Basel, Basel, Switzerland

Full list of author information is available at the end of the article
}

ovis and $B$. neotomae are the six classical species that infect mainly goats/sheep, cattle, pigs, dogs, sheep and rodents, respectively, while $B$. melitensis and B. abortus cause most of the human infections [2-4]. Like other Gram-negative bacteria, Brucellae express lipopolysaccharide (LPS), a major component of the outer membrane. The three structural components of LPS are the lipid A, the core oligosaccharide and the Opolysaccharide (O-antigen). In 'smooth' Brucella species, the O-polysaccharide is a linear polymer of 4,6-dideoxy-4formamido- $\alpha$-D-mannopyranosyl residues, whereas 'rough' 
strains have a truncated version without the $\mathrm{O}$-antigen $[5,6]$. Brucella LPS is able to induce protective antibodies [7-9], which are potentially important for serological diagnosis [10-16]. Because of the threat posed by natural outbreaks or by a deliberate release of the bacteria as a bioterror agent [17], there is a need for rapid and reliable identification systems, preferably based on multiplex formats covering a range of relevant species. This is especially important for fastidious agents such as Brucella or Francisella species where tracing by cultivation is hampered by long cultivation time.

The aim of this study was to develop a rapid and sensitive immunological assay to detect all Brucellae with 'smooth' LPS, particularly B. melitensis and B. abortus. To this end, monoclonal antibodies (mAbs) specific for Brucella LPS were generated and used to design a highly specific and sensitive antigen capture assay. An optimal combination of mAbs was identified and a Brucella LPS specific Luminex xMAP assay $[18,19]$ was developed, capable of detecting four of the major Brucella species (B. melitensis, B. abortus, B. suis, B. neotomae) with high sensitivity. Additionally, the Luminex assay works in a multiplex format, simultaneously detecting four category A and B bacterial bioterrorism agents and is suitable for detecting Brucella in complex samples.

\section{Methods}

\section{Ethics statement}

This study was carried out in strict accordance with the Rules and Regulations for the Protection of Animal Rights (Tierschutzverordnung) of the Swiss Federal Food Safety and Veterinary Office. The protocol was granted ethical approval by the Veterinary Office of the county of Basel-Stadt, Switzerland (Permit Number: 2375).

\section{Production and inactivation of bacteria}

Bacterial strains used in this study are listed in Table 1.

Brucella spp. were cultured on Columbia blood agar plates supplemented with $5 \%$ goat blood [20]. Bacteria were inactivated by $3 \%$ formalin $\left(55^{\circ} \mathrm{C}\right.$ for $\left.15 \mathrm{~min}\right)$, heat $\left(60{ }^{\circ} \mathrm{C}\right.$ for $\left.>20 \mathrm{~h}\right)$ or gamma $(\gamma)$ irradiation at $30-40 \mathrm{kGy}$ (Leoni Studer Hard AG, Däniken, Switzerland). Sterility was checked by incubating bacteria for three days on agar plates and no growth was observed.

\section{Production of anti-LPS mAbs}

To produce Brucella LPS-specific mAbs, mice carrying human immunoglobulin $C_{\gamma} 1$ heavy and $C_{k}$ light chain gene segments [21] were immunised four times subcutaneously with a dose of $10^{8} \mathrm{CFU}$ of differentially inactivated Brucella species, either adjuvant-free or as adjuvanted formulation, in combination with the Sigma Adjuvant System ${ }^{\circ}$ (SAS, Sigma Aldrich). Mice received either gamma $(\gamma)$ irradiated $B$. melitensis in
Table 1 Bacterial strains

\begin{tabular}{|c|c|c|c|}
\hline Bacterial species & Strain & $\begin{array}{l}\text { Inactivation } \\
\text { method }\end{array}$ & Source \\
\hline \multicolumn{4}{|c|}{ Brucella spp. (biotype) } \\
\hline \multirow[t]{3}{*}{ B. abortus (1) } & NCTC 10093544 & $\gamma$, formalin, heat & $S L$ \\
\hline & $19 S$ & formalin & $S L$ \\
\hline & A146-10 & formalin & RKI \\
\hline B. abortus (3) & A104-10 Uckermark & Y & RKI \\
\hline B. canis & NCTC 10854 RM-666 & formalin & $S L$ \\
\hline B. ovis & CNCTC 6741 & heat & RKI \\
\hline \multirow[t]{7}{*}{ B. melitensis (1) } & NCTC 1009416 M & $\gamma$, formalin, heat & $S L$ \\
\hline & ICM 3.33 & formalin & $S L$ \\
\hline & ICM 583/2003 & formalin & $S L$ \\
\hline & ICM 91/2004 & formalin & $S L$ \\
\hline & $102 \mathrm{A01C2F}$ & formalin & $S L$ \\
\hline & A146-13 & formalin & RKI \\
\hline & A104-11 Tgb. Nr. 117518 & Y & RKI \\
\hline B. melitensis (2) & A104-12 799/97, B3898 & Y & RKI \\
\hline B. melitensis (3) & A104-13 210739, Mainz & Y & RKI \\
\hline B. suis (1) & NCTC 103161330 & formalin & $S L$ \\
\hline B. suis (2) & A 104-14 Rostock & heat & RKI \\
\hline B. neotomae & A148-7 5 K33 & Y & RKI \\
\hline \multicolumn{4}{|l|}{ Other bacteria } \\
\hline $\begin{array}{l}\text { F. tularensis } \\
\text { tularensis }\end{array}$ & ATCC 6223 & formalin & $S L$ \\
\hline $\begin{array}{l}\text { F. tularensis } \\
\text { holarctica }\end{array}$ & LVS, NCTC 10857 & formalin & $S L$ \\
\hline \multirow{2}{*}{$\begin{array}{l}\text { B. anthracis } \\
\text { (spores) }\end{array}$} & Böhm 73202.2000 (PX02+) & formalin & $S L$ \\
\hline & Böhm A1 (PX01+) & formalin & $S L$ \\
\hline S. typhimurium & ATCC 14028 & formalin & $S L$ \\
\hline Y. enterocolitica & 310 (IT2, ST9) O9 & formalin & $S L$ \\
\hline Y. pestis & CO92 & $\gamma$, formalin & $S L$ \\
\hline O. anthropi & ATCC 49188 & formalin & $S L$ \\
\hline E. coli & O:157, 15326 & formalin & $S L$ \\
\hline B. mallei & NCTC 03709106 & formalin & $S L$ \\
\hline B. pseudomallei & H05410-0490 & formalin & $S L$ \\
\hline V. cholera & O1, ATCC 14734 & formalin & $S L$ \\
\hline
\end{tabular}

Bacteria were inactivated by $3 \%$ formalin, heat $\left(60^{\circ} \mathrm{C}\right.$ for $\left.>20 \mathrm{~h}\right)$ or gamma $(\gamma)$ irradiation (30-40 kGy). SL = Spiez Laboratory (Federal Office for Civil

Protection, Spiez, Switzerland). RKI = Robert Koch Institute (Berlin, Germany)

sterile Phosphate buffered saline (PBS, Sigma Aldrich), $\gamma$ irradiated B. melitensis with SAS, formalin inactivated $B$. melitensis in PBS or formalin inactivated $B$. abortus in PBS.

Three days before cell fusion, two selected mice received an intravenous booster injection with $10^{8} \mathrm{Bru}$ cella cells in PBS. Myeloma cells (PAI) were mixed 1:3 
(fusion 1) and 1:1 (fusion 2) with spleen cells from the corresponding mouse in Iscove's Modified Dulbecco's Medium (IMDM, Sigma Aldrich). Cells were fused with $1 \mathrm{~mL}$ of pre-warmed $\left(37^{\circ} \mathrm{C}\right)$ Polyethylene glycol (PEG 800, Roche), dissolved in $150 \mathrm{~mL}$ HAT selective medium (IMDM 1 \% 200 mM L-Glutamine (100X), 1 \% Pen/Strep (100X, [+] 10,000 Units/mL Penicillin [+] 10,000 $\mu \mathrm{g} / \mathrm{mL}$ Streptomycin, Gibco), 20 \% FBS, HAT media supplement 50X Hybri-Max ${ }^{\mathrm{Tm}}$, Sigma Aldrich) and cultured in 96-well tissue culture plates. Cells secreting Brucella-specific IgG were identified by ELISA coated with $\gamma$ irradiated B. melitensis cells $(16 \mathrm{M})$. From the two independent fusions, eleven hybridoma cell lines producing LPS specific mAbs were identified and cloned by limiting dilution. MAbs were purified from spent culture supernatant of the hybridoma clones by protein A affinity chromatography (HiTrap rProtein A FF, Amersham Biosciences). Purified mAbs were dialysed against PBS, aliquoted, and stored at $-80^{\circ} \mathrm{C}$.

\section{Enzyme-linked immunosorbent assay (ELISA)}

In indirect ELISA (iELISA), Maxisorp ${ }^{\mathrm{Tm}}$ microtitre plates (Nunc, Thermo Scientific) were coated for $36 \mathrm{~h}$ at $4{ }^{\circ} \mathrm{C}$ with $50 \mu \mathrm{L}$ of a $10 \mu \mathrm{g} / \mathrm{mL}$ solution of extracted LPS or with $50 \mu \mathrm{L}$ of a bacterial suspension containing $10^{7}$ inactivated Brucella cells per mL. Wells were then blocked with $5 \%$ milk powder in PBS for $2 \mathrm{~h}$, followed by three washings with PBS containing $0.25 \%$ Tween-20. Plates were incubated with appropriate dilutions of mouse sera or anti-LPS mAbs in PBS for $1-2 \mathrm{~h}$ at room temperature. After washing, plates were incubated with horseradish peroxidase-conjugated goat anti-mouse IgG $(\gamma$-chain specific) antibodies (Southern Biotech) for $1 \mathrm{~h}$. TMB (TMB Microwell Peroxidase Substrate System (2-C), KPL) or ABTS substrate (ABTS $^{\bullet}$ Peroxidase Substrate System, KPL) was added and incubated at room temperature until appropriate colour intensity was reached (five to $30 \mathrm{~min}$ ). The optical density (OD) of the reaction product was recorded after 5 to $30 \mathrm{~min}$ at $570 \mathrm{~nm}$ or $405 \mathrm{~nm}$ using a microplate reader.

In antigen capture ELISA (cELISA), microtitre plates were coated with $50 \mu \mathrm{L}$ of a $10 \mu \mathrm{g} / \mathrm{mL}$ solution of unlabelled mAbs in PBS. After being blocked and washed, wells were incubated with dilutions of inactivated $\mathrm{Bru}$ cella cells in PBS. Biotinylated detection mAbs $(10 \mu \mathrm{g} /$ $\mathrm{mL}$ ) were added and incubated for $1 \mathrm{~h}$. After repeated washing, streptavidin-peroxidase polymer conjugate (1 $\mu \mathrm{g} / \mathrm{mL}$, Sigma Aldrich) was added and developed with the ABTS substrate.

Isotypes of anti-LPS mAbs were determined by detecting mAbs bound to anti-mouse lambda light chain antibody-coated plates with alkaline phosphataseconjugated antibodies specific for mouse IgG1, IgG2a, IgG2b or IgG3 (Southern Biotech).

\section{Sodium dodecyl sulfate-polyacrylamide gel electrophoresis (SDS-PAGE) and immunoblotting}

Aliquots of extracted LPS from B. melitensis and $B$. abortus were mixed with sample buffer (Laemmli buffer, Invitrogen) and heated for $15 \mathrm{~min}$ at $96{ }^{\circ} \mathrm{C}$ before loading on 4-12\% Bis-Tris gels. SeeBlue pre-stained protein standard (Invitrogen) was used as a molecular weight marker. Following gel electrophoresis, LPS was transferred electrophoretically to nitrocellulose membranes. Blots were blocked for $2 \mathrm{~h}$ with $5 \%$ milk powder in PBS, cut into strips and then incubated with purified mAbs $(10 \mu \mathrm{g} / \mathrm{mL})$ for $1 \mathrm{~h}$. The strips were washed four times for 15 min with PBS containing $0.05 \%$ Tween-20 and incubated with alkaline phosphatase-conjugated goat anti-mouse IgG heavy-chain antibodies (Sigma Aldrich) for $1 \mathrm{~h}$. Strips were treated with 5-bromo-4-chloro-3indolylphosphate and nitroblue tetrazolium to visualise bands.

\section{Immunofluorescence assay (IFA)}

$30 \mu \mathrm{L}$ droplets of a fixing solution containing $4 \%$ paraformaldehyde and $10 \%$ PBS were placed in each well of a pre-coated Poly-L-Lysin microscope glass slide (Diagnostic Microscope Slides ES-242B-AD-CE24, Thermo Scientific). Ten $\mu \mathrm{L}$ of a bacterial suspension containing $10^{8} \gamma$ irradiated B. melitensis (16 M) or B. abortus (544) cells were added to each well and incubated for $30 \mathrm{~min}$ at room temperature. Wells were washed five times with PBS and then incubated for 15 min with $50 \mu \mathrm{L}$ of blocking buffer containing $1 \%$ fatty acid-free bovine serum albumin (BSA) in PBS. Afterwards, $30 \mu \mathrm{L}$ of $10 \mu \mathrm{g} / \mathrm{mL}$ mAbs diluted in blocking buffer were added and incubated for $1 \mathrm{~h}$. Wells were washed five times with blocking buffer before $30 \mu \mathrm{L}$ of detection antibody (Alexa Fluor $568(2 \mathrm{mg} / \mathrm{mL}$, Invitrogen) conjugated donkey anti-mouse IgG $(\mathrm{H}+\mathrm{L}), 1: 400$ in blocking buffer) was added for an additional hour. Finally, wells were washed five times, mounted with ProLong ${ }^{\ominus}$ Gold antifade reagent with 4',6-diamidino-2-phenylindole (DAPI, Invitrogen) and covered with a coverslip. Antibody binding and DNA staining were assessed by fluorescence microscopy.

\section{Luminex assay}

Anti-LPS mAbs were coupled to magnetic beads (BioPlex Pro Magnetic $\mathrm{COOH}$ Beads, Biorad) according to the manufacturer's instructions and adjusted to a working concentration of 40 beads $/ \mu \mathrm{L}$ in blocking buffer $(1 \%$ BSA in PBS). In the coupling reaction, $6 \mu \mathrm{g}$ of antibody was applied to $5 \times 10^{5}$ beads. Fifty $\mu \mathrm{L}$ of working bead mixture was used per microtitre well. Fifty $\mu \mathrm{L}$ bacterial samples were then added to each bead-containing well and incubated for $2 \mathrm{~h}$ on a microplate shaker at $37{ }^{\circ} \mathrm{C}$ in the dark. After incubation, the plates were washed with PBS containing $0.05 \%$ Tween-20 and the beads were 
resuspended in $50 \mu \mathrm{L}$ of biotinylated detection antibody at a concentration of $10 \mu \mathrm{g} / \mathrm{mL}$ in blocking buffer and incubated for $1 \mathrm{~h}$. After repeated washing, $50 \mu \mathrm{L}$ of a streptavidin-R phycoerythrin (ProZyme Inc.) solution was added and incubated for $30 \mathrm{~min}$. The plate was then washed and the beads resuspended in $125 \mu \mathrm{L}$ of blocking buffer before loading onto the BioPlex 200 instrument (Bio-Rad Laboratories). Reporter fluorescence was measured and expressed as mean fluorescence intensity of at least 100 beads per region. Multiplexed assays were performed in a single well format with mAb pairs 3D12/ 10G1 (Brucellae), MTA1/MTD6 [19], YPF19/YPF19 [22] and T14/FB11 [23].

\section{Statistical analysis}

All data were obtained from experiments performed in duplicate (at a minimum). Antigen-free controls consisted of PBS (instead of sample suspended in PBS) and were further diluted with the diluent used for the particular assay. These controls were included in each experiment to determine the cut-off. Mean value, standard deviation and LOD (limit of detection) were calculated in Excel. Figure assembly, data transformation and nonlinear regression (sigmoidal curve, dose-response variable slope) were done with GraphPad Prism.

\section{Results}

\section{Generation and characterisation of Brucella LPS-specific mAbs}

Two mice exhibiting high ELISA IgG titres against $B$. melitensis (16 M) or B. abortus (NCTC 10093 544) cells after immunisation with inactivated bacterial cells were chosen for the generation of Brucella LPS-specific mAbs. Eleven hybridoma cell clones were obtained by screening with a $B$. melitensis $(16 \mathrm{M}, \gamma$ irradiated, $5 \times$ $10^{7} \mathrm{CFU} / \mathrm{mL}$ ) whole cell ELISA. Two mAbs (3A10 and 4. F11) were generated from a mouse immunised with $\gamma$ irradiated B. melitensis, and nine (1A3, 10G1, 3D12, 2G12, 2G2, 1B6, 2E3, 5B10, 1E2) from a mouse immunised with formalin inactivated $B$. abortus cells. Determination of the mouse IgG subclass of the produced LPS-specific mAbs showed a predominance of the $\operatorname{IgG} 2 \mathrm{~b}(\lambda)$ isotype; only mAbs $4 \mathrm{~F} 11$ and $1 \mathrm{E} 2$ were of the $\operatorname{IgG} 3(\lambda)$ isotype. While all $11 \mathrm{mAbs}$ recognised extracted LPS from $B$. abortus (type A O-antigen), mAbs 1E2 and 4. F11 showed a markedly weaker reactivity with $B$. melitensis LPS (type $\mathrm{M} \mathrm{O}$-antigen) than did the others in ELISA (Fig. 1a) and Western blotting (Fig. 1c). The Western blot profiles (Fig. 1c) were typical for 'smooth' LPS of Brucella sp. [24]. In immunofluorescence analysis with inactivated $B$. melitensis and $B$. abortus cells, all anti-LPS mAbs yielded a homogenous circular surface staining. Figure $1 \mathrm{~b}$ shows a representative staining for mAbs 3D12 and 10G1 with B. melitensis cells. The differences in the fine-specificities of the mAbs observed in ELISA correlated with differences in immunofluorescence analysis, where surface staining by mAbs 1E2 and 4. F11 with B. melitensis cells was weak (data not shown). For the analysis of the samples under biosafety level two conditions, inactivation is required. Different methods, $\gamma$ irradiation, formalin inactivation and heat treatment, are available for that. Irrespective of the inactivation method, the anti-LPS mAbs reacted with $B$. melitensis and $B$. abortus cells in ELISA (Fig. 1d).

To develop a highly sensitive antigen capture assay, a suitable combination of a capturing and a biotinylateddetecting $\mathrm{mAb}$ was selected from the pool of $11 \mathrm{mAbs}$. In a sandwich ELISA format, the majority of mAb combinations tested were suitable for detecting $B$. melitensis cells (Fig. 2). Despite its weak reactivity with $B$. melitensis LPS, mAb 1E2 could effectively be used as a capture antibody but it failed to interact with $B$. melitensis cells when used as a detection antibody. A differentiation between $B$. melitensis and B. abortus cells was thus only observed with mAb 1E2 as a detection antibody (data not shown). MAb 3D12 performed best as an antigen capture antibody while mAb 10G1 was selected as the detection antibody as it gave the highest read out in combination with mAb 3D12 as the capture antibody. Hence, further development focussed on the mAb pair 3D12/10G1.

\section{Developing a Luminex assay for rapid and sensitive detection of Brucella spp.}

The mAb pair 3D12/10G1 was used to develop an antigen capture assay based on Luminex xMAP technology. While similar to ELISA in overall assay format, the Luminex technology combines advanced fluidics, optics, and digital signal processing with up to 500 color-coded microspheres to provide an accurate measurement of multiple analytes from a single sample [25]. Each bead set can be conjugated to a specific biomolecule (such as an antibody) to capture analytes of interest using a very small sample volume. Here, the mAb 3D12 was coupled to magnetic beads and used as the capture antibody, and the biotinylated mAb 10G1 was used as the detection antibody. The sensitivity of this Luminex assay was determined by analysing serial dilutions of inactivated $B$. melitensis, B. abortus and B. suis cells. The limit of detection (LOD) was calculated as the mean fluorescence intensity of the blank plus three times the standard deviation (SD) and set as the threshold (dashed line in Fig. 3a). The detection limits in a sample volume of $50 \mu \mathrm{L}$ were $2 \times 10^{2}$ cells per $\mathrm{mL}$ for $B$. melitensis, $5 \times 10^{3}$ cells per $\mathrm{mL}$ for $B$. abortus and $8 \times 10^{4}$ cells per $\mathrm{mL}$ for $B$. suis. Depending on the species tested, the sensitivity of the Luminex assay was 4 to 50 times higher than that of a corresponding antigen capture ELISA (Fig. 3b), 


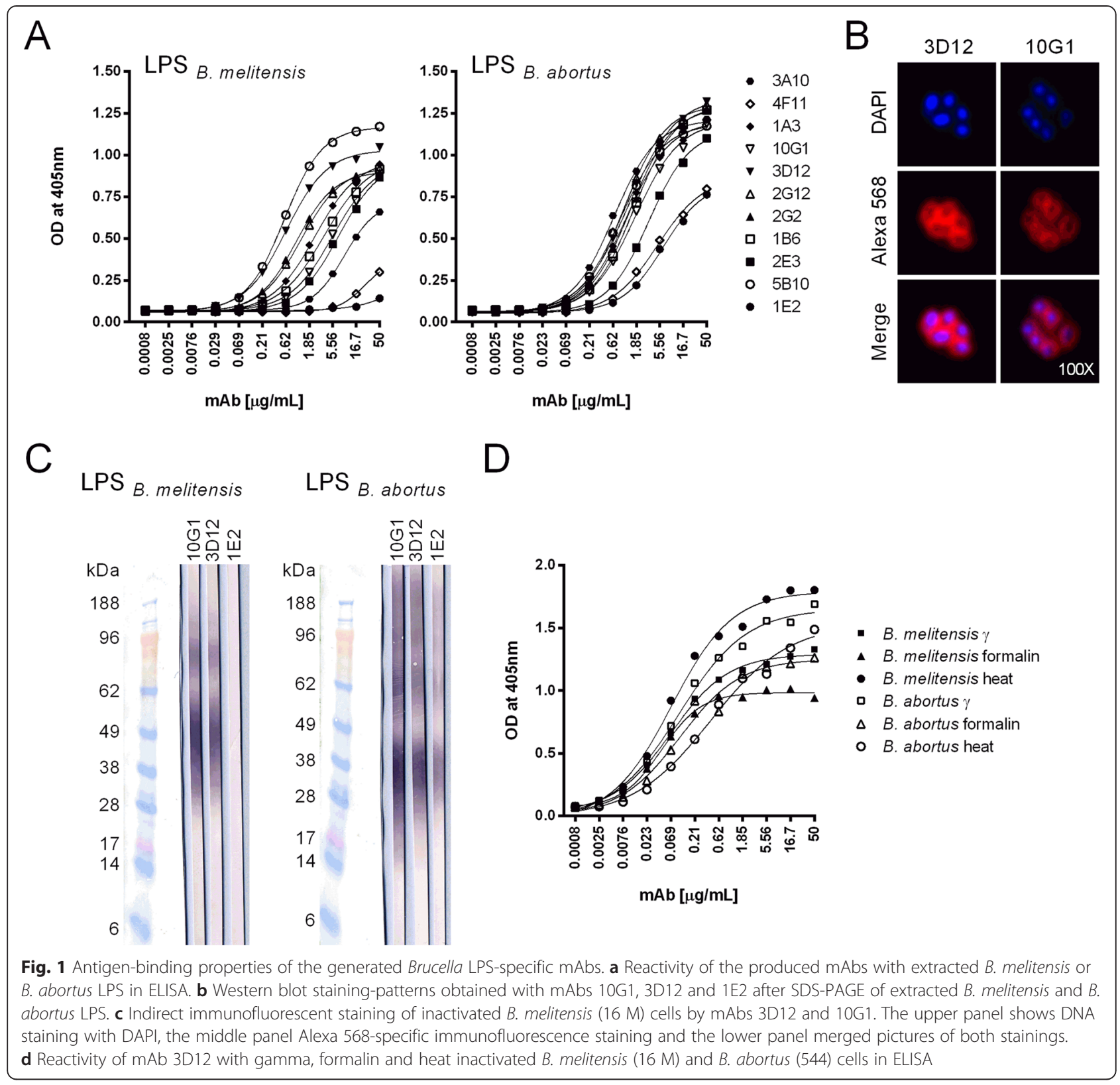

where at least $10^{4}, 2 \times 10^{4}$ and $3 \times 10^{6}$ cells per $\mathrm{mL}$, respectively, were required for accurate detection.

The specificity of the bead-based assay was tested with several biotypes of $B$. melitensis (1-3), B. abortus $(1,3)$, $B$. suis $(1,2), B$. canis, B. ovis and B. neotomae, as well as with other potential bioterror agents ( $F$. tularensis, $B$. anthracis, S. typhimurium, Y. pestis, B. mallei, B. pseudomallei [1]) and bacteria (Y. enterocolitica O9, E. coli $O 157$ and $V$. cholera $O 1$ [26-29]) with structurally similar O-antigens of $\alpha 1,2$-linked 4-amino-4,6-dideoxy- $\alpha$-Dmannopyranosyl subunits and $O$. anthropi, the closest relative of Brucellae [30]. The Luminex assay detected all 'smooth' Brucella species (B. melitensis, B. abortus, B. suis and $B$. neotomae) independently of their biotype
(Table 2). Overall, Brucella species expressing the M Oantigen were detected with higher sensitivity compared to A or AM O-antigen expressing Brucella. Crossreactivity with $Y$. enterocolitica $O 9$ was found, as predicted by the structural identity of the type A O-antigen $[27,28]$. Neither B. canis nor B. ovis cells expressing a 'rough' LPS nor any of the other bacterial species tested gave positive signals.

The newly developed singleplex assay for Brucella spp. was integrated into a previously established multiplex assay to allow for simultaneous detection of the four potential bioterror agents, B. melitensis, B. anthracis, $F$. tularensis and $Y$. pestis, in a single run of the assay. Mixed samples containing combinations of the four 


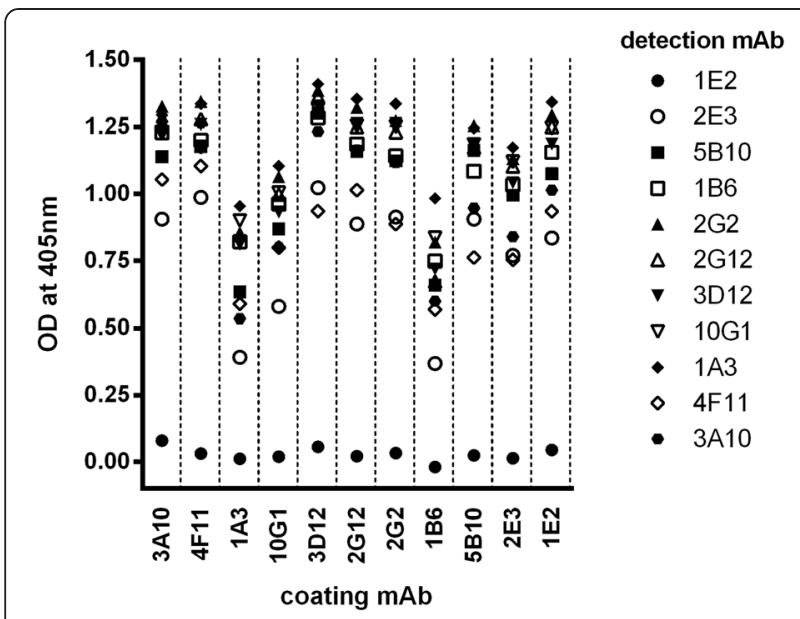

Fig. 2 Comparative testing of mAb pairs in an antigen capture ELISA. To evaluate optimal antibody combinations, each of the 11 mAbs was used as a capture or detection (biotin-conjugate) antibody at a concentration of $10 \mu \mathrm{g} / \mathrm{mL}$. Optical densities were measured for each antibody combination using gamma-irradiated $B$. melitensis $(16 \mathrm{M})$ cells at a concentration of $10^{7}$ cells $/ \mathrm{mL}$

bacterial species were prepared in PBS and tested in the multiplexed immunoassay format (Fig. 4a). All four biothreat agents tested were accurately detected and no cross-reactivities between individual singleplex assays were observed. The specificity of the Luminex assay for $B$. anthracis, $F$. tularensis and $Y$. pestis had been tested prior to the multiplex testing (Additional files 1 and 2).

In addition, the multiplex assay specifically identified all four bacterial species from a spiked milk sample, indicating that the newly developed Luminex assay is also suitable for detecting Brucella spp. in complex biological samples (Fig. 4b).

\section{Discussion}

Brucellosis is one of the most common bacterial zoonosis worldwide and an important cause of economic losses and human suffering [2, 4]. Moreover, $B$. abortus, $B$. melitensis and B. suis could be developed as bioterrorism agents due to their ability to undergo aerosolization [31]. Isolation by cultivation is the standard method for identifying Brucella bacteria in biological samples, but may take up to 4 weeks to complete. Methods based on the polymerase chain reaction that identifies nucleic acid fragments from bacteria are becoming more practical for detecting Brucella spp. [32, 33]. However, according to international biodefense regulations, immunological detection methods for potential bioterror agents are required in addition to molecular detection and identification assays.

In this study, we showed that Brucella O-antigenspecifc mAbs represent potent immuno-capturing components for a highly sensitive detection system for Brucella cells in complex samples. Immunisation of laboratory mice with inactivated Brucella bacteria combined with a B. melitensis whole cell ELISA for selecting B-cell hybridoma lines that produce Brucella-specific antibodies yielded exclusively LPS-specific mAbs, although antiprotein IgG antibodies could also be detected in the serum of the immunised mice (data not shown). This observation might be explained by the fact that in 'smooth' Brucella species, outer membrane proteins and other membrane components are masked by O-polysaccharide chains of

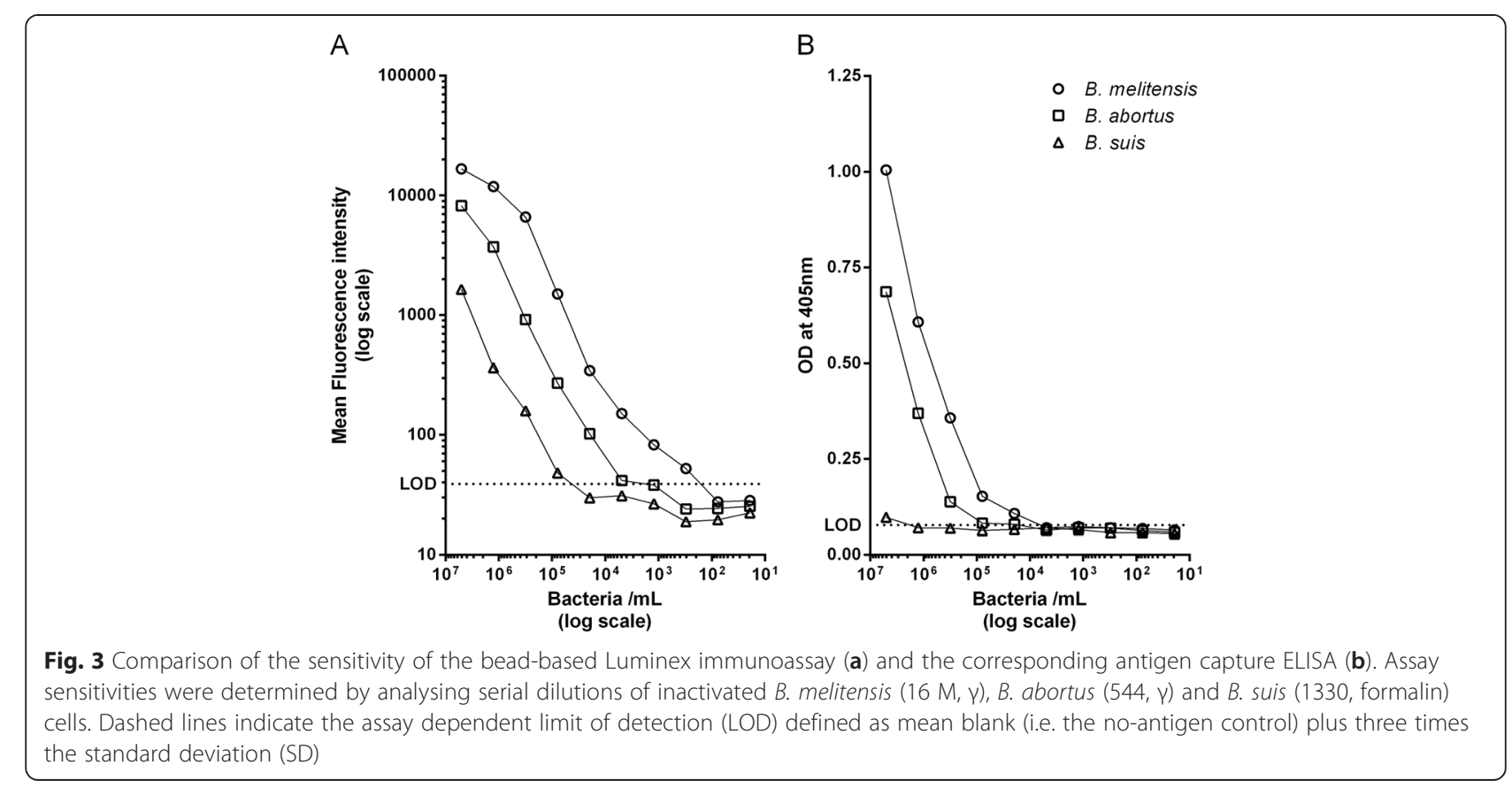


Table 2 Specificity of the developed bead-based Luminex immunoassay

\begin{tabular}{|c|c|c|c|}
\hline Bacterial species & Strain & O-Antigen & Luminex assay (mean fluorescence intensity) \\
\hline \multicolumn{4}{|l|}{ Brucella spp. (biotype) } \\
\hline \multirow[t]{3}{*}{ B. abortus (1) } & NCTC 10093544 & $A^{1,3}$ & 13107 \\
\hline & $19 S$ & $A^{1,3}$ & 11300 \\
\hline & A146-10 & $A^{1,3}$ & 5607 \\
\hline B. abortus (3) & A104-10 Uckermark & $A^{1,3}$ & 3172 \\
\hline B. canis & NCTC 10854 RM-666 & $R^{2,3}$ & 33 \\
\hline B. ovis & CNCTC 6741 & $R^{2,3}$ & 23 \\
\hline \multirow[t]{7}{*}{ B. melitensis (1) } & NCTC 1009416 M & $M^{1,3}$ & 25860 \\
\hline & ICM 3.33 & $M^{1,3}$ & 13129 \\
\hline & ICM 583/2003 & $M^{1,3}$ & 16972 \\
\hline & ICM 91/2004 & $M^{1,3}$ & 15030 \\
\hline & $102 \mathrm{~A} 01 \mathrm{C} 2 \mathrm{~F}$ & $M^{1,3}$ & 22285 \\
\hline & A146-13 & $M^{1,3}$ & 11407 \\
\hline & A104-11 Tgb. Nr. 117518 & $M^{1,3}$ & 5977 \\
\hline B. melitensis (2) & A104-12 799/97, B3898 & $A^{1,3}$ & 2958 \\
\hline B. melitensis (3) & A104-13 210739, Mainz & $\mathrm{AM}^{1,3}$ & 1884 \\
\hline B. suis (1) & NCTC 103161330 & $A^{1,3}$ & 5167 \\
\hline B. suis (2) & A 104-14 Rostock & $A^{1,3}$ & 10316 \\
\hline B. neotomae & A148-7 5 K33 & $A^{1,3}$ & 1875 \\
\hline \multicolumn{4}{|l|}{ Other bacteria } \\
\hline F. tularensis tularensis & ATCC 6223 & $D^{4}$ & 18 \\
\hline F. tularensis holarctica & NCTC 10857 & $D^{4}$ & 22 \\
\hline B. anthracis (spores) & Böhm 73202.2000 (PX02) & $D^{5}$ & 19 \\
\hline S. typhimurium & ATCC 14028 & $D^{6}$ & 19 \\
\hline Y. enterocolitica & 310 (IT2, ST9) O9 & $A^{7,8,9}$ & 1291 \\
\hline Y. pestis & CO92 & $\mathrm{R}^{10}$ & 20 \\
\hline O. anthropi & ATCC 49188 & $D^{11}$ & 20 \\
\hline E. coli & 0157,15326 & $A^{7,12}$ & 22 \\
\hline B. mallei & NCTC 03709106 & $D^{13}$ & 18 \\
\hline B. pseudomallei & H05410-0490 & $D^{14}$ & 20 \\
\hline V. cholera & O1, ATCC 14734 & $A^{15}$ & 24 \\
\hline
\end{tabular}

Luminex LOD was defined as two times the mean fluorescence intensity of the blank (mean blank $=20$ ) and used as the threshold for positive results. Values in bold indicate positive results. Classification of O-antigens [4, 26-29, 41-50]: A=a1,2-linked 4-amino-4,6-dideoxy-a-D-mannopyranosyl subunits, $M=a 1,3$-linked and a1,2-linked 4,6-dideoxy-4-formamido-a-D-mannopyranosyl residues, $\mathrm{D}=$ different O-antigen structure compared to Brucella, $\mathrm{R}=$ 'rough' $\mathrm{LPS}$ (no O-antigen). Meikle et al. $1989^{1}$, Adone et al. $2011^{2}$, Corbel $2006^{3}$, Wang et al. $2011^{4}$, Crich and Vinogradova $2007^{5}$, Watson et al. $1992^{6}$, Perry et al. $1986^{7}$, Caroff et al. 1984 ${ }^{8}$, Bundle et al. $1984^{9}$, Skurnik et al. $2000^{10}$, Velasco et al. $1996^{11}$, Perry and Bundle $1990^{12}$, Burtnick et al. $2002^{13}$, Perry et al. $1995^{14}$, Kenne et al. $1982^{15}$

LPS [34, 35]. All of the mAbs generated recognised LPS from $B$. abortus (type A O-antigen) and from $B$. melitensis (type $\mathrm{M}$ O-antigen). However, mAbs $1 \mathrm{E} 2$ and 4 F11 differed from the other mAbs in fine-specificity in that they showed a markedly reduced reactivity with $B$. melitensis LPS. None of the sample inactivation methods tested (gamma irradiation, formalin and heat treatment) affected the interaction between the mAbs produced and the bacterial cells, corroborating the suitability of Brucella LPS as a stable target antigen for detection. Dependent on infrastructural constraints (i.e. availability of gamma irradiation) and application, laboratories may have different preferences concerning the inactivation method.

As expected from the comparative binding studies, the majority of the mAb combinations tested were suitable for detecting Brucella cells in a sandwich capture ELISA format. A differentiation between B. melitensis and other Brucella species expressing 'smooth' LPS was achieved with $\mathrm{mAb} 1 \mathrm{E} 2$ in a suitable test format. The Luminex immunoassay with the selected mAb pair, 3D12 and 10G1, captured and detected cells of all 'smooth' Brucella species and biotypes tested but also showed cross- 

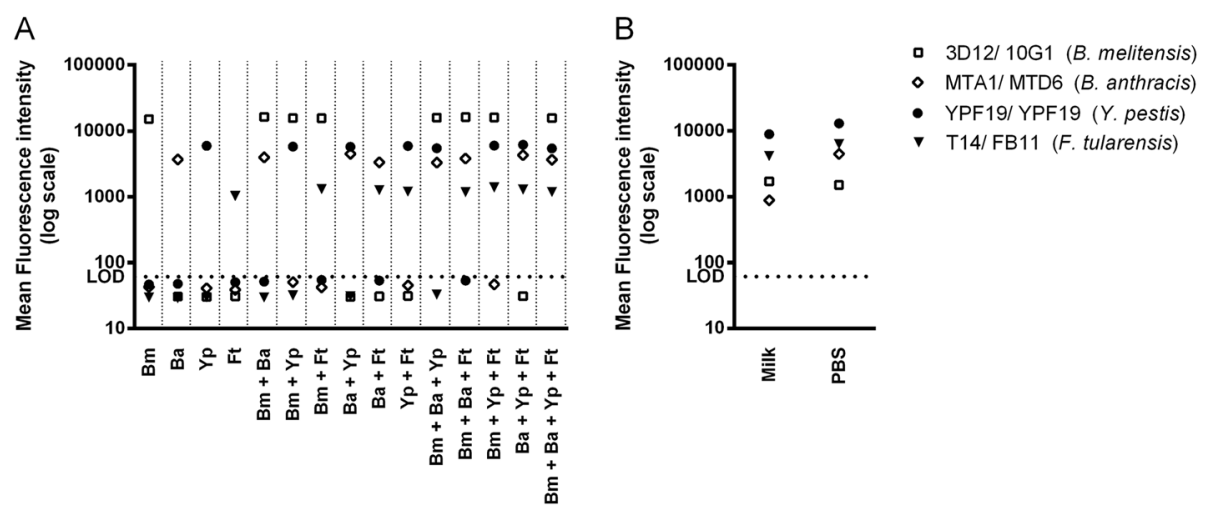

Fig. 4 Multiplexed Luminex immunoassay for detecting potential bioterror agents, B. melitensis, B. anthracis, F. tularensis and Y. pestis. a Test samples

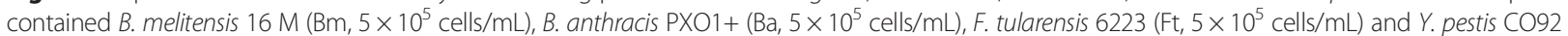
(Yp, $5 \times 10^{4}$ cells $/ \mathrm{mL}$ ) cells in PBS either alone or in combination. In (b), PBS and milk samples were spiked with all four bacterial species and used at a concentration of $2.5 \times 10^{6}$ cells/mL. MAbs 3D12, MTA1, T14 and YPF19, coupled to distinct magnetic beads, were used as capture antibodies and the biotinylated mAbs 10G1, MTD6, FB11 and YPF19 were used for detection. Reporter dye fluorescence intensities measured for each bead set are shown. Dashed lines indicate the limit of detection (LOD) defined as mean blank plus three times the standard deviation

reactivity with $Y$. enterocolitica serotype O9. The-Oantigens of $Y$. enterocolitica O9, E. coli O157, $V$. cholera $O 1$ and $B$. abortus all consist of a linear polymer of $\alpha 1,2-$ linked 4-amino-4,6-dideoxy- $\alpha$-D-mannopyranosyl residues (perosamine). However, they differ in the $N$-acylation of the perosamine sugar [26]. While B. abortus and $Y$. enterocolitica $O 9$ are $\mathrm{N}$-acylated with formic acid, $V$. cholera $\mathrm{O} 1$ are substituted with (S)-2,4-dihydroxybutanoic acid [36]. These derivatisations can have major effects on antibody binding, which may explain why our mAbs only showed cross-reactivity with $Y$. enterocolitica O9. PCR can verify whether a result obtained with mAb pair 3D12/ 10D1 is true or false positive due to $Y$. enterocolitica $O 9$ contamination. To conclusively analyse environmental samples a combination of molecular and immunological methods is recommended [37]. Our mAbs are specific to Brucella carrying 'smooth' LPS, hence a detection of 'rough' Brucella species is not possible. A LPS-independent detection based on surfaceexposed structures might solve this problem.

Depending on the Brucella species tested, the assay was able to detect 10 to 4000 cells in a sample volume of $50 \mu \mathrm{L}$. Currently available molecular identification assays for Brucella spp. offer comparable or even lower detection limits [32, 33, 38].

Recently, a capture ELISA for diagnostic purposes was developed using LPS-specific monoclonal antibodies to detect LPS antigens in the blood [39]. Both, our approach for generating LPS-specific monoclonal antibodies, as well as the overall purpose of our test development were different. We developed a highly sensitive Luminex multiplex assay for the detection of biological threat agents both in natural outbreak and bio-threat situations.

The conversion of the ELISA into the Luminex beadbased assay markedly increased the sensitivity for detecting Brucella and allowed integration of the Brucella assay into a multiplex assay to simultaneously detect a range of relevant bio-threat species. The multiplexed immunodetection assay accurately detected Brucella spp., B. anthracis, F. tularensis and $Y$. pestis cells within a single mixed sample. Brucellosis is transmitted to humans through consumption of unpasteurised dairy products or through direct contact with infected animals. Although detecting Brucella cells in milk is complicated [40], the Luminex multiplex assay specifically identified all tested bacterial species from spiked milk samples, demonstrating that the developed assay is a suitable tool for detecting Brucella cells in complex samples.

\section{Conclusion}

The Luminex assay described here is a suitable tool for specifically detecting Brucella spp. even in complex samples such as milk. Four bio-threat agents can be detected in the multiplex format, quickly and specifically. Overall, using the Luminex assay together with common molecular and cultivation methods is crucial to fulfilling international biodefense regulations for rapidly and reliably identifying biological threat agents. In the future, the Luminex assay may also be considered for detecting Brucella in clinical samples.

\section{Additional files}

Additional file 1: Additional bacterial strains (Bacillus, Yersinia, Francisella) included in the study. (PDF $279 \mathrm{~kb}$ )

Additional file 2: Specificity of the developed bead-based Luminex immunoassay for B. anthracis, F. tularensis and Y. pestis. (PDF $170 \mathrm{~kb}$ )

Competing interests

The authors declare that they have no competing interests. 


\section{Authors' contributions}

AS, MT, NS and GP conceived and designed the experiments. AS and MT performed the experiments. AS, MT, MW, NS and GP analysed the data. AS, MT, NS and GP wrote the paper and all authors read and approved the final manuscript.

\section{Authors' information}

Not applicable.

\section{Acknowledgements}

We thank Marcelle Holzer and Susanne Thomann from the Swiss Federal Office for Civil Protection for technical assistance. We acknowledge the support of the Robert Koch Institute, in the framework of the European project QUANDHIP, for providing inactivated strains and Prof. David R. Bundle from the University of Alberta (Canada) for providing extracted LPS of B. melitensis and B. abortus.

\section{Author details}

'Department of Medical Parasitology and Infection Biology, Swiss Tropical and Public Health Institute, Basel, Switzerland. ${ }^{2}$ University of Basel, Basel, Switzerland. ${ }^{3}$ Federal Office for Civil Protection, Spiez Laboratory, Spiez, Switzerland.

Received: 2 June 2015 Accepted: 25 September 2015

\section{Published online: 05 October 2015}

\section{References}

1. Centers for Disease Control and Prevention. Emergency Preparedness and Response. Specific Hazards. Bioterrorism. http://www.bt.cdc.gov/ bioterrorism. Accessed 9 Sept 2013

2. Atluri $\mathrm{VL}$, Xavier MN, de Jong MF, den Hartigh AB, Tsolis RM. Interactions of the human pathogenic Brucella species with their hosts. Annu Rev Microbiol. 2011;65:523-41.

3. Whatmore AM. Current understanding of the genetic diversity of Brucella, an expanding genus of zoonotic pathogens. Infect Genet Evol. 2009:9:1168-84

4. Corbel MJ. Brucellosis in humans and animals. WHO. 2006. http:// www.who.int/csr/resources/publications/Brucellosis.pdf. Accessed 4 Sept 2013.

5. Cardoso PG, Macedo GC, Azevedo V, Oliveira SC. Brucella spp noncanonical LPS: structure, biosynthesis, and interaction with host immune system. Microb Cell Fact. 2006;5:13

6. Kubler-Kielb J, Vinogradov E. Reinvestigation of the structure of Brucella Oantigens. Carbohydr Res. 2013;378:144-7.

7. Cloeckaert A, Jacques I, de Wergifosse P, Dubray G, Limet JN. Protection against Brucella melitensis or Brucella abortus in mice with immunoglobulin $\mathrm{G}(\operatorname{lgG}), \lg A$, and $\lg M$ monoclonal antibodies specific for a common epitope shared by the Brucella A and M smooth lipopolysaccharides. Infect Immun. 1992:60:312-5

8. Limet J, Plommet A-M, Dubray G, Plommet M. Immunity conferred upon mice by anti-LPS monoclonal antibodies in murine Brucellosis. Annales de I'Institut Pasteur / Immunologie. 1987:138:417-24.

9. Limet JN, Bosseray N, Garin-Bastuji B, Dubray G, Plommet M. Humoral immunity in mice mediated by monoclonal antibodies against the $\mathrm{A}$ and $\mathrm{M}$ antigens of Brucella. J Med Microbiol. 1989;30:37-43.

10. Araj GF. Update on laboratory diagnosis of human brucellosis. Int J Antimicrob Agents. 2010;36 Suppl 1:S12-7.

11. Beninati C, Garibaldi M, Lo Passo C, Mancuso G, Papasergi S, Garufi G, et al. Immunogenic mimics of Brucella lipopolysaccharide epitopes. Peptides. 2009:30:1936-9.

12. Diaz-Aparicio E, Marin C, Alonso-Urmeneta B, Aragon V, Perez-Ortiz S, Pardo $M$, et al. Evaluation of serological tests for diagnosis of Brucella melitensis infection of goats. J Clin Microbiol. 1994;32:1159-65.

13. Franco MP, Mulder M, Gilman RH, Smits HL. Human brucellosis. Lancet Infect Dis. 2007:7:775-86.

14. Lucero NE, Foglia L, Ayala SM, Gall D, Nielsen K. Competitive enzyme immunoassay for diagnosis of human brucellosis. J Clin Microbiol. 1999;37:3245-8

15. Ulu-Kilic A, Metan G, Alp E. Clinical presentations and diagnosis of brucellosis. Recent Pat Antiinfect Drug Discov. 2013;8:34-41.
16. Poester FP, Nielsen K, Samartino LE, Yu WL. Diagnosis of brucellosis. Open Veterinary Science Journal. 2010;4:46-60.

17. Wenger A, Mauer V, Dunn M. International Biodefense Handbook. An Inventory of National and International Biodefense Practices and Policies. Center for Security Studies. 2007. http://www.isn.ethz.ch/Digital-Ubrary/ Publications/Detail/?ots591=0c54e3b3-1e9c-be1e-2c24a6a8c7060233\&lng=en\&id=31146. Accessed 2 April 2014.

18. Baker HN, Murphy R, Lopez E, Garcia C. Conversion of a capture ELISA to a Luminex XMAP assay using a multiplex antibody screening method. J Vis Exp. 2012. doi:10.3791/4084.

19. Tamborrini M, Holzer M, Seeberger PH, Schurch N, Pluschke G. Anthrax spore detection by a luminex assay based on monoclonal antibodies that recognize anthrose-containing oligosaccharides. Clin Vaccine Immunol. 2010;17:1446-51.

20. Marianelli C, Graziani C, Santangelo C, Xibilia MT, Imbriani A, Amato R, et al. Molecular epidemiological and antibiotic susceptibility characterization of Brucella isolates from humans in Sicily, Italy. J Clin Microbiol. 2007:45:2923-8.

21. Pluschke G, Joss A, Marfurt J, Daubenberger C, Kashala O, Zwickl M, et al. Generation of chimeric monoclonal antibodies from mice that carry human immunoglobulin Cgamma1 heavy of Ckappa light chain gene segments. J Immunol Methods. 1998;215:27-37.

22. HyTest. Turku, Finland. 2003. http://www.hytest.fi/product/yersinia-pestis-f1antigen-antibody. Accessed 8 Oct 2013.

23. HyTest. Turku, Finland. 2003. http://www.hytest.fi/product/francisellatularensis-Ips-antibody. Accessed 8 Oct 2013

24. Zygmunt MS, Jacques I, Bernardet N, Cloeckaert A. Lipopolysaccharide heterogeneity in the atypical group of novel emerging Brucella species. Clin Vaccine Immunol. 2012;19:1370-3.

25. Wu W, Zhang S, Qu J, Zhang Q, Li C, Li J, et al. Simultaneous detection of IgG antibodies associated with viral hemorrhagic fever by a multiplexed Luminex-based immunoassay. Virus Res. 2014.

26. Perry MB, Bundle DR. Antigenic relationships of the lipopolysaccharides of Escherichia hermannii strains with those of Escherichia coli 0157:H7, Brucella melitensis, and Brucella abortus. Infect Immun. 1990;58:1391-5.

27. Caroff M, Bundle DR, Perry MB. Structure of the O-chain of the phenolphase soluble cellular lipopolysaccharide of Yersinia enterocolitica serotype O:9. Eur J Biochem. 1984;139:195-200.

28. Bundle DR, Gidney MA, Perry MB, Duncan JR, Cherwonogrodzky JW. Serological confirmation of Brucella abortus and Yersinia enterocolitica 0:9 O-antigens by monoclonal antibodies. Infect Immun. 1984;46:389-93.

29. Perry MB, MacLean L, Griffith DW. Structure of the O-chain polysaccharide of the phenol-phase soluble lipopolysaccharide of Escherichia coli 0:157:H7. Biochem Cell Biol. 1986;64:21-8.

30. Cloeckaert A, Tibor A, Zygmunt MS. Brucella outer membrane lipoproteins share antigenic determinants with bacteria of the family Rhizobiaceae. Clin Diagn Lab Immunol. 1999;6:627-9.

31. Doganay GD, Doganay M. Brucella as a potential agent of bioterrorism Recent Pat Antiinfect Drug Discov. 2013;8:27-33.

32. Romero C, Lopez-Goni I. Improved method for purification of bacterial DNA from bovine milk for detection of Brucella spp. by PCR. Appl Environ Microbiol. 1999;65:3735-7.

33. Leal-Klevezas DS, Lopez-Merino A, Martmez-Soriano JP. Molecular detection of Brucella spp.: rapid identification of B. abortus biovar I using PCR. Arch Med Res. 1995:26:263-7.

34. Cloeckaert A, de Wergifosse P, Dubray G, Limet JN. Identification of seven surface-exposed Brucella outer membrane proteins by use of monoclonal antibodies: immunogold labeling for electron microscopy and enzymelinked immunosorbent assay. Infect Immun. 1990;58:3980-7.

35. Bowden RA, Cloeckaert A, Zygmunt MS, Bernard S, Dubray G. Surface exposure of outer membrane protein and lipopolysaccharide epitopes in Brucella species studied by enzyme-linked immunosorbent assay and flow cytometry. Infect Immun. 1995;63:3945-52

36. Kenne $L$, Unger $P$, Wehler $T$. Synthesis and nuclear magnetic resonance studies of some $\mathrm{N}$-acylated methyl 4-amino-4,6-dideoxy-a-Dmannopyranosides. J Chem Soc Perkin. 1988:1:1183-6.

37. Peruski AH, Peruski LF. Immunological methods for detection and identification of infectious disease and biological warfare agents. Clin Diagn Lab Immunol. 2003;10:506-13.

38. Vanlalhmuaka, Thavachelvam K, Tuteja U, Sarika K, Nagendra S, Kumar S. Reverse line blot macroarray for simultaneous detection and 
characterization of four biological warfare agents. Indian J Microbiol. 2013;53:41-7.

39. Patra KP, Saito M, Atluri VL, Rolan HG, Young B, Kerrinnes T, et al. A proteinconjugate approach to develop a monoclonal antibody-based antigen detection test for the diagnosis of human brucellosis. PLoS Negl Trop Dis. 2014;8, e2926.

40. Meisel S, Stockel S, Elschner M, Melzer F, Rosch P, Popp J. Raman spectroscopy as a potential tool for detection of Brucella spp. in milk. Appl Environ Microbiol. 2012;78:5575-83.

41. Meikle PJ, Perry MB, Cherwonogrodzky JW, Bundle DR. Fine structure of A and $\mathrm{M}$ antigens from Brucella biovars. Infect Immun. 1989;57:2820-8.

42. Adone R, Muscillo M, La Rosa G, Francia M, Tarantino M. Antigenic, immunologic and genetic characterization of rough strains B. abortus RB51, B. melitensis B115 and B. melitensis B18. PLoS One. 2011;6:e24073.

43. Wang Q, Shi X, Leymarie N, Madico G, Sharon J, Costello CE, et al. A typical preparation of Francisella tularensis O-antigen yields a mixture of three types of saccharides. Biochemistry. 2011;50:10941-50.

44. Crich D, Vinogradova O. Synthesis of the antigenic tetrasaccharide side chain from the major glycoprotein of Bacillus anthracis exosporium. J Org Chem. 2007;72:6513-20.

45. Watson DC, Robbins JB, Szu SC. Protection of mice against Salmonella typhimurium with an O-specific polysaccharide-protein conjugate vaccine. Infect Immun. 1992;60:4679-86.

46. Skurnik M, Peippo A, Ervela E. Characterization of the O-antigen gene clusters of Yersinia pseudotuberculosis and the cryptic O-antigen gene cluster of Yersinia pestis shows that the plague bacillus is most closely related to and has evolved from Y. pseudotuberculosis serotype O:1 b. Mol Microbiol. 2000;37:316-30.

47. Velasco J, Moll H, Vinogradov EV, Moriyon I, Zahringer U. Determination of the O-specific polysaccharide structure in the lipopolysaccharide of Ochrobactrum anthropi LMG 3331. Carbohydr Res. 1996;287:123-6.

48. Burtnick MN, Brett PJ, Woods DE. Molecular and physical characterization of Burkholderia mallei O antigens. J Bacteriol. 2002;184:849-52.

49. Perry MB, MacLean LL, Schollaardt T, Bryan LE, Ho M. Structural characterization of the lipopolysaccharide $\mathrm{O}$ antigens of Burkholderia pseudomallei. Infect Immun. 1995;63:3348-52.

50. Kenne L, Lindberg B, Unger P, Gustafsson B, Holme T. Structural studies of the Vibrio cholerae o-antigen. Carbohydr Res. 1982;100:341-9.

\section{Submit your next manuscript to BioMed Central and take full advantage of:}

- Convenient online submission

- Thorough peer review

- No space constraints or color figure charges

- Immediate publication on acceptance

- Inclusion in PubMed, CAS, Scopus and Google Scholar

- Research which is freely available for redistribution 